\title{
Toxicological evaluations of combined administration of ethanolic stem bark extract of Enantia chlorantha and lisinopril in experimental type 2 diabetes
}

Emmanuel Oladipo Ajani ${ }^{*}$ and Latifat Bolanle Ibrahim

\begin{abstract}
Background: Enantia chlorantha is a local medicinal plant commonly use in Nigeria for the treatment of diabetes but without support of scientific data. Large percentage of people suffering from diabetes who uses the plant as antidiabetic agent also combine its administration with standard antihypertensive drugs.

Aim: In the present study, we have investigated the possible toxicological effects of combined administration of $E$. chlorantha bark extract and lisinopril in diabetic model of experimental rats.

Methods: E. chlorantha stem bark was extracted by cold maceration of the pulverised stem bark in $70 \%$ ethanol. The acute toxicity effect of the plant was then evaluated in rats following oral administration of single dose of the extract. Diabetes was induced by intraperitoneal administration of $40 \mathrm{mg} / \mathrm{kg}$ streptozotocin into fructose fed rat. Diabetic rats were then randomly assigned into 6 groups of 7 rats each. One group was kept as the diabetic model while separate treatments were administered to the other six groups. Seven non diabetic rats were kept as the control group and administered normal saline.

Results: The $\mathrm{LD}_{50}$ of E. chlorantha stem bark was above $5000 \mathrm{mg} / \mathrm{kg}$. Combined administration of lisinopril and $E$. chlorantha showed synergistic effects in the restoration of renal biomarkers (serum creatinine, urea, $\mathrm{Na}^{+}$ and $\mathrm{K}^{+}$), cardiac function biomarkers (CK-MB and $\left.L D H\right)$ and hematological parameters (RBC, WBC, HGB and PCV), while antagonistic effects were however observed with some of the liver biomarkers (AST, ALT, ALP, GGT, total protein and total bilirubin). Rats co-administered lisinopril and E. chlorantha also showed fatty liver with cholestasis.
\end{abstract}

Conclusion: The study concluded that diabetes is associated with kidney and cardiac dysfunction. Combined administration of lisinopril and E. chlorantha though may not aggravate these dysfunctions however, it may antagonize the efficacy of the plant in ameliorating liver dysfunction in diabetics.

Keywords: Pharmacodynamics, Drug-herb interaction, Toxicity, Liver function, Diabetes

\footnotetext{
* Correspondence: Emmanuel.ajani@kwasu.edu.ng

Phytomedicine, Toxicology and Drug Development Laboratory, Department

of Medical Biochemistry and Pharmacology, School of Basic Medical

Sciences, Kwara State University, Malete, P. M. B, Ilorin 1530, Nigeria
}

\section{Springer Open}

( ) The Author(s). 2020 Open Access This article is licensed under a Creative Commons Attribution 4.0 International License, which permits use, sharing, adaptation, distribution and reproduction in any medium or format, as long as you give appropriate credit to the original author(s) and the source, provide a link to the Creative Commons licence, and indicate if changes were made. The images or other third party material in this article are included in the article's Creative Commons licence, unless indicated otherwise in a credit line to the material. If material is not included in the article's Creative Commons licence and your intended use is not permitted by statutory regulation or exceeds the permitted use, you will need to obtain permission directly from the copyright holder. To view a copy of this licence, visit http://creativecommons.org/licenses/by/4.0/. 


\section{Introduction}

The use of more than one drug (polypharmacy) is a common practice in the treatment of chronic disorders such as diabetes mellitus, hypertension, single and multiple disorders which occur simultaneously. In such a situation, one drug may interact with other drug (drugdrug interactions) or with herb (herb-drug interaction). Herb-Drug interactions (HDIs) are either pharmacodynamic (PD) or pharmacokinetic (PK) in nature. For the former, this occurs when co-administered herbs and conventional medicines enhance or negate each other's effects as a result of similar or disparate pharmacological activity [7]. Pharmacodynamic interactions on the other hand arise from the ability of the herb to modulate the absorption, distribution, metabolism and/or excretion (ADME) of the drug.

Diabetes mellitus (DM) is a major degenerative disease in the world today afflicting many lives both in the developed and developing countries [25]. Increasing incidence of diabetes in the developing countries, especially in the younger age group, affecting mainly the people in the productive years of their lives is of great concern [18]. The chronic hyperglycaemia of diabetes is associated with long-term damage, dysfunctions, and failure of different organs, especially the eyes, kidneys, nerves, heart, and blood vessels $[3,20]$. Type 2 diabetes (T2DM) is the most common form and comprises of $90 \%$ of people with diabetes around the world [11]. Type 2 diabetes is characterized by the combination of peripheral insulin resistance and inadequate insulin secretion by pancreatic beta cells [5, 13]. Diabetes mellitus of long duration is associated with several complications such as atherosclerosis, myocardial infarction, nephropathy etc. These complications have long been assumed to be related to chronic elevation of glucose levels. The management of diabetes mellitus is one of the many disease states where multiple-drug therapy is inevitable and often used to the benefit of the patients.

According to the World Health Organization [35], 40$60 \%$ of type 2 diabetics are obese, and have an increased likelihood of developing Coronary Artery Disease (CAD) and other atherosclerotic manifestations including hypertension. Mohan et al. [21] also reported that the prevalence of CAD was $21.4 \%$ among diabetics, compare to $9.1 \%$ in those with normal glucose tolerance. In such a situation, there may be need for polypharmacy and hence chances for interactions between antidiabetic and antihypertensive drugs, which may be beneficial or harmful. Consequently, there is a need to monitor drug therapy in polypharmacy in order to gain a better therapeutic effect with a lower rate of risk.

Enantia chlorantha belongs to annonaceae family. This plant is commonly known as African yellow wood. Among the Yorubas in Nigeria, it is known as Awopa, Osu pupa or dokita igbo [1]. In the traditional medicine, this plant has been used for a long time in many parts of the African continent to treat various ailments of the human body. Many of these uses are supported by some studies. For example, a report by Tsabang et al. [33] indicated that a decoction of $500 \mathrm{~g}$ of stem bark in three liters of water for $20 \mathrm{~min}$ may be used to treat malaria symptoms, aches, wounds, boils, vomiting, yellow fever, chills, sore, and hepatitis. Although, the combine use of Enanthia chlorantha stem bark and antihypertensive drug is a common practice in Nigeria, previous findings from our laboratory showed that the therapeutic efficacy of the plant is not influenced when co-administered with lisinopril (an oral long-acting angiotensin converting enzyme inhibitor). The present study was set up to evaluate the toxicological implications of combine use of the two agents in diabetes condition. This is with a view to evaluate the risk associated with the combine administration of the two agents.

\section{Methodology \\ Chemicals and drugs}

Streptozocin was a product of Sigma- Aldrich, USA. Metformin (glucophage $500 \mathrm{mg}$ ) was manufactured by Merck santé, France and lisiofil (lisinopril) was manufactured by Fourrts (India) Laboratories Pvt. Limited. All the reagent kits used for bioassay were sourced from RANDOX Laboratories Ltd., Crumlin, Co. Antrim, UK. All other chemicals used were of analytical grade and sourced from the Biochemistry laboratory, Kwara State University.

\section{Plant collection, identification and crude extract preparation}

The stem bark of E. chlorantha was obtained from Oja tuntun, Ilorin, Kwara State in June 2018. The plant sample was identified and authenticated at the department of Plant Biology, University of Ilorin, Kwara State, Nigeria. A voucher number UIH/001/1356 was assigned to the plant and a sample specimen was thereafter deposited in the Herbarium. The stem bark was cleaned to remove adhering dirt, air-dried for 2 weeks and ground into powder using an electric blender. Extraction was carried out by cold maceration of $800 \mathrm{~g}$ of the coarse powder with $5 \mathrm{~L}$ of $70 \%$ ethanol for $72 \mathrm{~h}$, with constant shaking. The resultant mixture was filtered using Whatman filter paper (No.1) and the filtrate was concentrated using a rotary evaporator at $40{ }^{\circ} \mathrm{C}$. Aliquot portions of the extract were weighed and the final yield was determined to be $12.5 \%$. The extract was finally reconstituted in distilled water for use in the study.

\section{Experimental protocols \\ Experimental animals}

The sub-chronic toxicity study was carried out on healthy forty-nine (49) male Wistar rats weighing 
between 164 and $176 \mathrm{~g}$ while the acute toxicity studies was carried out on nine male Wistar rats weighing between 119 and $122 \mathrm{~g}$. The rats were obtained from Can farm Ilorin and housed in cages at the animal house of the Department of Medical Biochemistry and Pharmacology, Kwara State University, Malete, Nigeria. The rats were acclimatized for 14 days and fed with commercial diets and water ad libitum. They were all maintained at $25 \pm 2{ }^{\circ} \mathrm{C}$ light and dark cycle of $12 / 12 \mathrm{~h}$ respectively.

\section{Acute toxicity test}

The acute toxicity test was performed using the OECD guidelines 423 [20, 24]. Standard two-phase approach described by Lorke [17] was used. Nine rats of average weight $120.09 \pm 2.51 \mathrm{~g}$ were used for this study. The rats were divided at random into three groups of three rats each in the first phase. The rats were first deprived of feed and water for $12 \mathrm{~h}$. Groups I, II and III were orally treated with ethanolic stem bark extract of $E$. chlorantha at $10 \mathrm{mg} / \mathrm{kg}, 100 \mathrm{mg} / \mathrm{kg}$ and $1000 \mathrm{mg} / \mathrm{kg}$ body weight respectively. They were then observed for $48 \mathrm{~h}$ for signs of toxicity or mortality. In the second phase of the experiment, the remaining three rats were assigned into three groups (IV, V and VI) of one animal each and thereafter administered $1600 \mathrm{mg} / \mathrm{kg}, 2900 \mathrm{mg} / \mathrm{kg}$ and $5000 \mathrm{mg} / \mathrm{kg}$ body weight of the extract respectively. The rats were thereafter carefully observed individually after dosing. The observation was done once during the first $30 \mathrm{~min}$, periodically during the first $24 \mathrm{~h}$, with special attention given during the first $4 \mathrm{~h}$ and daily thereafter, for a total of 14 days. All the rats were then subjected to detailed gross necropsy by careful examination of the external surface of the body, all orifices and cranial, thoracic and abdominal cavities. Behavioral changes, lethargy, depression, salivation, diarrhea, muscular weakness, sedation and ailment signs were also observed. The $\mathrm{LD}_{50}$ was thereafter estimated based on the mortality observed in each group adopting the method of Ajani et al. [2].

\section{$\mathrm{LD}_{50} \geq$ Maximum-dose $\mathrm{Y} /$ number of rats per group}

$$
\text { Where } \mathrm{Y}=\text { Sum of mean death }
$$

\section{Induction of diabetes}

Type 2 diabetes was induced following the method of Wilson and Islam [34]. The rats were first fed 15\% fructose solution $(\mathrm{w} / \mathrm{v})$ for 4 weeks, after which they were fasted overnight and thereafter administered streptozotocin $(40 \mathrm{mg} / \mathrm{kg}$ i.p) freshly prepared in $0.1 \mathrm{M}$ sodium citrate buffer. The diabetic state was confirmed $72 \mathrm{~h}$ after streptozotocin injection. All rats having fasting blood glucose levels greater than $200 \mathrm{mg} / \mathrm{dl}$ were considered diabetic.

\section{Sub-acute oral toxicity study}

Animal grouping/administration Forty- two (42) diabetic rats were randomly assigned to 6 groups consisting of 7 rats each. The rats were labelled and treated as follow; Diabetic model group (DM); Diabetic treated groups (administered $E$. chlorantha [T1], Glucophage [T2], E. chlorantha + Glucophage [T3], Lisinopril [T4], and lisinopril + Glucophage [T5]). Another 7 rats (non-diabetic) were kept as the control group (NC). The extract was administered at 200 $\mathrm{mg} / \mathrm{kg}$ dose while glucophage and lisinopril were administered at $7.14 \mathrm{mg} / \mathrm{kg}$ and $0.14 \mathrm{mg} / \mathrm{kg}$ dose respectively. All administrations were carried out orally as a single dose daily by gavage for 4 weeks. The rats were housed in rat cages in the animal facility center at the department of Medical Biochemistry and Pharmacology, Kwara State University, Malete, Nigeria. The rats were maintained in accordance with the principles of laboratory animal care [22] guidelines. The experiment protocol was designed according to the Department Animal Ethics Committee guidelines. Twenty- four hours after the last administration and under mild diethylether anesthesia, the animals were sacrificed and blood was obtained from the jugular vein. Blood sample was transferred into plain centrifuge tube and allowed to clot at room temperature. It was then centrifuged within $1 \mathrm{~h}$ of collection at $4000 \mathrm{x}$ g for $10 \mathrm{~min}$ to obtain the serum.

\section{Assay procedure \\ Biochemical and Haematological assay}

Liver, renal and cardiac function parameters were evaluated according to manufacturer's instructions on the assay kits. Serum Aspartate Aminotransferase (AST) and Alanine Aminotransferase (ALT) were assayed for by Reitman and Frankel [29] method. Alkaline Phosphatase (ALP) and Lactate Dehydrogenase (LDH) were assayed according to the recommendations of the Deutsche Gesellschaft fur Klinische Chemie [36]. $\gamma$-glutamyl transferase (GGT) was assayed for by Reitman and Frankel [29] method while total protein was assayed for by Peters [26] method. Total bilirubin was assayed for by RomaBikai et al. [30] method and creatine kinase (CK-MB) was assayed for using enzyme immunoassay technique [6]. Creatinine was assayed for by Tietz et al. [32] method. The plasma concentrations of sodium $\left(\mathrm{Na}^{+}\right)$ and potassium ions $\left(\mathrm{K}^{+}\right)$were determined by Flame Photometry using Coming 410C Flame Photometer. Urea was assayed by Fawcett and Scott (1960) method. Automated hematological analyzer Sysmex, KX-21 (Japan) was used to analyzed haematological parameters.

\section{Histopathological evaluation}

The rats were quickly dissected and the liver and pancreas isolated, blotted with clean tissue paper and cleaned of fat. These were then used for histological 
examination. The method of Thapa and Anuj [31] was adapted for the histopathological examination of the harvested liver sections. Microscopic features of the cells of the treated rats were compared with both normal and the model groups.

\section{Data analysis}

All statistical analysis was performed with SPSS software version 16.0. Data are expressed as the means standard error of mean (S.E.M). Student's t-test and analysis of variance (ANOVA) were employed in comparing means of continuous variables as appropriate. Differences were considered statistically significant if $p<0.05$.

\section{Results}

\section{Acute oral toxicity study}

Ethanolic extract of $E$. chlorantha bark did not show any toxic or adverse effect nor mortality at $5000 \mathrm{mg} / \mathrm{kg}$ dose. There was no observable clinical adverse effect of substance related toxicity on the behavioral responses of the tested rats during the 14 days monitoring period (Table 1). Physical observations also indicated that all the rats behaved essentially normal with no signs of changes in the skin, fur, eyes, mucous membrane, behavioural patterns and tremors. Salivation and diarrhea were not evident following single oral dosing in the tested rats.

\section{Sub-acute oral toxicity study Liver function test}

The result showed a significant increase in serum activities of all the enzymes (AST, ALT, ALP, GGT) evaluated in the untreated diabetic rats (model group) when compared with the control group (Table 2). Treatment with the extract restored the enzyme activities to the control values. The enzyme activities obtained in the rats treated with the extract alone were significantly lower than that of the diabetic rats treated with glucophage alone and were also lower than that of diabetic rats coadministered glucophage and lisinopril and that of the rats co-treated with the extract and lisinopril. The Table also showed that the enzyme activity obtained in the diabetic rats treated with lisinopril alone was higher than

Table 1 Result of acute toxicity study

\begin{tabular}{llll}
\hline Group & Dose $(\mathrm{mg} / \mathrm{kg})$ & Sign of toxicity $(\mathrm{ST} / \mathrm{NB})^{*}$ & Mortality $(\mathrm{D} / \mathrm{S})^{*}$ \\
\hline Group I & 10 & $0 / 3$ & $0 / 3$ \\
Group II & 100 & $0 / 3$ & $0 / 3$ \\
Group III & 1000 & $0 / 3$ & $0 / 3$ \\
Group IV & 1600 & $0 / 1$ & $0 / 1$ \\
Group V & 2900 & $0 / 1$ & $0 / 1$ \\
Group VI & 5000 & $0 / 1$ & $0 / 1$ \\
\hline
\end{tabular}

*: ST sign of toxicity, NB normal behavior, $D$ died, $S$ survived Values are expressed as number of animals that of the control group (NC) but it was however significantly lower than that of the diabetic model group. Similar results were obtained with total protein and bilirubin levels.

\section{Kidney function test}

Table 3 is the result of the effects of treatments on some serum biomarkers of kidney functions (urea, creatinine, $\mathrm{Na}^{+}$and $\mathrm{K}^{+}$. The result showed a significant increase in serum urea, creatinine, $\mathrm{Na}^{+}$and $\mathrm{K}^{+}$level in rats administered streptozotocin without treatment (model group) when compared with the control group. Treatment with the extract restored the serum levels of all the biomarkers to the control values. When compared among the treatment groups, the serum urea in the group administered glucophage although lower than that of the model group, was however higher than the value obtained in the control group. The observed serum urea level of the extract treated rats was however not significantly different from all other treatment groups. No significant difference $(p>0.05)$ was observed among the treatment groups for all other biomarkers of kidney functions monitored in the study.

\section{Cardiac function}

The result showed a significant increase in serum CK and LDH activities in rats administered streptozotocin without treatment (model group) when compared with the control group (Table 4). Treatment with the extract reduced the serum creatinine kinase activity below the observed activity in the model group. The observed activity was however higher than that of the control (NC) value. The result also showed that the lactate dehydrogenase activity of the extract treated rat was not significantly different from that of the model group. Combined administration of the extract and lisinopril however brought the lactate dehydrogenase activity to the pretreatment value though the observed value was not significantly different from that of the model group.

\section{Haematological evaluation}

Table 5 is the result of the effects of treatments on total erythrocyte, leucocyte, haemoglobin and PCV levels. The result showed a significant decrease in total erythrocyte, haemoglobin and PCV levels in rats administered streptozotocin without treatment (model group) when compared with the control group. Treatment with the extract restored the values of all these parameters. Similar results were obtained with all other treatment groups. The total erythrocyte, haemoglobin and leucocyte level obtained in the rats treated with the extract alone was not significantly different from that of all other treatment groups. The Table also showed that the PCV obtained for the rats co-administered the extract and 
Table 2 Effect of combined administration of lisinopril and ethanolic extract of E. chlorantha on serum biomarkers of liver function

\begin{tabular}{|c|c|c|c|c|c|c|c|}
\hline Group & Treatment & AST (U/I) & $\mathrm{ALT}(\mathrm{U} / \mathrm{I})$ & $\mathrm{ALP}(\mathrm{U} / \mathrm{I})$ & GGT (U/I) & Total protein & Total Bilirubin \\
\hline NC & Distilled water only & $30.36 \pm 2.45^{\mathrm{a}}$ & $29.69 \pm 0.83^{\mathrm{a}}$ & $1.04 \pm 0.76^{\mathrm{a}}$ & $0.25 \pm 0.84^{a}$ & $0.79 \pm 0.82^{d}$ & $0.93 \pm 0.31^{a}$ \\
\hline DM & STZ-fructose+ distilled water & $77.68 \pm 4.67^{\mathrm{e}}$ & $85.80 \pm 1.04^{d}$ & $1.54 \pm 0.54^{d}$ & $1.14 \pm 0.60^{d}$ & $1.50 \pm 0.47^{\mathrm{a}}$ & $2.46 \pm 0.53^{c}$ \\
\hline $\mathrm{T} 1$ & Extract only & $37.10 \pm 2.68^{\mathrm{ab}}$ & $42.60 \pm 4.70^{b}$ & $1.14 \pm 0.16^{b c}$ & $0.52 \pm 0.15^{\mathrm{bc}}$ & $0.90 \pm 0.10^{c}$ & $1.22 \pm 0.18^{\mathrm{a}}$ \\
\hline $\mathrm{T} 2$ & Glucophage only & $44.70 \pm 1.23^{b c}$ & $39.38 \pm 3.79^{a b}$ & $1.07 \pm 0.74^{\mathrm{b}}$ & $0.48 \pm 0.03^{b c}$ & $0.93 \pm 0.29^{d}$ & $1.14 \pm 0.35^{\mathrm{a}}$ \\
\hline T3 & Extract + Lisinopril & $48.70 \pm 0.96^{c}$ & $56.98 \pm 1.72^{c}$ & $1.29 \pm 0.53^{c}$ & $0.71 \pm 0.26^{c}$ & $0.78 \pm 0.13^{b}$ & $1.62 \pm 0.59^{a}$ \\
\hline T4 & Glucophage + Lisinopril & $47.42 \pm 2.03^{b}$ & $49.12 \pm 2.15^{\mathrm{bc}}$ & $1.26 \pm 0.65^{c}$ & $0.68 \pm 0.31^{c}$ & $0.81 \pm 0.03^{b}$ & $1.05 \pm 0.44^{\mathrm{a}}$ \\
\hline T5 & Lisinopril only & $60.25 \pm 4.63^{d}$ & $55.88 \pm 2.07^{\complement}$ & $1.39 \pm 0.05^{d}$ & $0.97 \pm 0.13^{d}$ & $1.07 \pm 0.20^{b}$ & $1.83 \pm 0.34^{b}$ \\
\hline
\end{tabular}

Results are mean \pm SD of seven determinations

Values in the same column with similar superscripts $(a, b, c$ or $d)$ are not significantly $(p>0.05)$ different from each other

lisinopril was higher than the control value and that observed in the rats treated with the extract alone.

\section{Histopathology}

An overall histopathology shown in Fig. 1a-g indicates that there were no alterations in the histological presentation of the tissue of the normal control group after the experimental period (1a). The photomicrograph of the model group however showed a fatty liver (1b). The photomicrograph of the extract treated (1c), the glucophage treated (1d), glucophage +lisinopril treated (1f) and lisinopril treated rats showed a manifestation that were similar to that of the control group. When the diabetic rats were however co-administered with the extract and lisinopril, the liver histology (1e) showed a fatty liver with cholestasis. The histology of the control rats showed normal manifestation of the histoarchitecture of the pancreas (2a) whereas large interlobular duct and diminished expression of islet cells were observed in the pancreatic tissue of the model group (2b). The histoarchitecture of other treatment groups $(2 \mathrm{c}-\mathrm{g})$ were similar to that of the diabetic model group.

\section{Discussion}

Streptozotocin (STZ)-fructose type 2 model shares a number of features with human type 2 diabetes mellitus (T2DM) both histologically and metabolically and is characterized by moderate stable hyperglycaemia, hence, STZ-fructose induced diabetes model was used in this study. Streptozotocin injection caused $\beta$ cells degeneration in rats, resulting in decrease in the release of insulin by the pancreas. Furthermore, high fructose ingestion causes insulin resistance (IR) thereby resulting in hyperglycaemia. Result of fasting blood glucose of $\geq 200 \mathrm{mg} / \mathrm{dl}$ obtained in this study confirms induction of type 2 diabetes in STZ-fructose administered rats. This is similar to the findings of earlier researchers $[16,19]$.

The ethanolic bark extract of $E$. chlorantha was found to cause no toxicity during the acute toxicity study even at $5000 \mathrm{mg} / \mathrm{kg}$ dose hence, a dose of $200 \mathrm{mg} \mathrm{Kg-}^{1}$ was used in this study for the sub-acute toxicity evaluation. In the present study, untreated diabetic rats showed increased activities of liver enzymes. Numerous studies have reported that diabetes is associated with raised serum activities of liver enzymes [10,23]. A large clinical study reported that patients who were overweight (BMI $\left.25-30 \mathrm{~kg} / \mathrm{m}^{2}\right)$ and obese $\left(\mathrm{BMI}>30 \mathrm{~kg} / \mathrm{m}^{2}\right)$ are more likely to have elevated serum levels of liver enzymes [9]. Results from this study show that concurrent use of both lisinopril and E. chlorantha did not produce a better effect in restoring the serum liver biomarkers when compared with the single treatment of the extract. ACE-Is such as lisinopril are known to induce liver injury, and two cases of ACE-I induced cirrhosis has been

Table 3 Effect of combined administration of lisinopril and ethanolic bark extract of E. chlorantha on serum urea, creatinine, $\mathrm{Na}^{+}$ and $\mathrm{K}^{+}$level in type 2 diabetes rats

\begin{tabular}{|c|c|c|c|c|c|}
\hline Groups & Treatments & Urea $(\mathrm{mg} / \mathrm{ml})$ & Creatinine $(\mathrm{mg} / \mathrm{ml})$ & Sodium $\left(\mathrm{Na}^{+}\right)(\mathrm{mmol} / \mathrm{L})$ & Potassium $\left(\mathrm{K}^{+}\right)(\mathrm{mmol} / \mathrm{L})$ \\
\hline$\overline{N C}$ & Distilled water & $13.30 \pm 2.67^{\mathrm{a}}$ & $1.030 \pm 0.19^{\mathrm{a}}$ & $1.384 \pm 0.94^{\mathrm{a}}$ & $3.54 \pm 1.19^{a}$ \\
\hline DM & STZ-fructose+ distilled water & $45.69 \pm 1.07^{b}$ & $3.169 \pm 1.06^{b}$ & $0.965 \pm 0.78^{b}$ & $10.10 \pm 0.90^{b}$ \\
\hline $\mathrm{T} 1$ & Extract only & $19.89 \pm 3.12^{c}$ & $1.269 \pm 0.46^{\mathrm{a}}$ & $1.375 \pm 0.44^{\mathrm{a}}$ & $6.63 \pm 1.65^{\mathrm{a}}$ \\
\hline $\mathrm{T} 2$ & Glucophage only & $27.44 \pm 4.21^{c}$ & $1.948 \pm 0.44^{\mathrm{a}}$ & $1.255 \pm 0.86^{a}$ & $7.60 \pm 0.74^{\mathrm{a}}$ \\
\hline T3 & Extract + Lisinopril & $15.56 \pm 3.91^{\mathrm{a}}$ & $1.069 \pm 0.93^{\mathrm{a}}$ & $1.177 \pm 1.46^{\mathrm{a}}$ & $5.16 \pm 1.16^{\mathrm{a}}$ \\
\hline T4 & Glucophage + Lisinopril & $18.82 \pm 4.14^{\mathrm{a}}$ & $1.459 \pm 0.37^{a}$ & $1.153 \pm 1.14^{\mathrm{a}}$ & $6.43 \pm 1.89^{a}$ \\
\hline T5 & Lisinopril only & $12.84 \pm 0.83^{a}$ & $1.392 \pm 0.48^{\mathrm{a}}$ & $1.364 \pm 0.61^{\mathrm{a}}$ & $5.51 \pm 0.62^{\mathrm{a}}$ \\
\hline
\end{tabular}

Results are mean \pm SD of seven determinations

Values in the same column with similar superscripts $(a, b$ or $c)$ are not significantly $(p>0.05)$ different from each other 
Table 4 Effect of combined administration of lisinopril and ethanolic bark extract of E. chlorantha on serum CK and LDH activities

\begin{tabular}{|c|c|c|c|}
\hline Group & Treatment & Creatine kinase-MB & $\begin{array}{l}\text { Lactate dehydrogenase } \\
\text { activity }((\mathrm{U} / \mathrm{L})\end{array}$ \\
\hline $\mathrm{NC}$ & Distilled water & $13.57 \pm 4.32^{a}$ & $0.837 \pm 0.82^{a}$ \\
\hline DM & STZ-fructose+ distilled water & $43.64 \pm 5.36^{b}$ & $1.878 \pm 0.13^{b}$ \\
\hline $\mathrm{T} 1$ & Extract only & $20.24 \pm 1.89^{c}$ & $1.469 \pm 0.20^{b}$ \\
\hline $\mathrm{T} 2$ & Glucophage only & $17.74 \pm 4.74^{\mathrm{a}}$ & $1.357 \pm 0.50^{a, b}$ \\
\hline T3 & Extract + Lisinopril & $13.78 \pm 3.74^{\mathrm{a}}$ & $1.135 \pm 0.17^{a, b}$ \\
\hline $\mathrm{T} 4$ & Glucophage + Lisinopril & $14.32 \pm 0.87^{\mathrm{a}}$ & $1.075 \pm 0.87^{a, b}$ \\
\hline T5 & Lisinopril only & $16.07 \pm 2.37^{\mathrm{a}}$ & $1.121 \pm 0.83^{\mathrm{a}, \mathrm{b}}$ \\
\hline
\end{tabular}

Results are mean \pm SD of seven determinations

Values in the same column with similar superscripts $(a, b$ or $c)$ are not significantly $(p>0.05)$ different from each other

previously reported [8]. The long term effect of coadministration as shown by the histology of the liver suggest that combined administration of lisinopril and $E$. chlorantha may potentiate hepatotoxicity. This may however not be the case when the extract is administered alone. Previous evidence suggests that diabetic condition is associated with changes in morphology and eventually functional alteration in kidneys [14]. The present results clearly support this report. Our study demonstrated increased levels of kidney function markers; creatinine and urea in serum of diabetic untreated group. In contrast, all extract treated rats showed significant reduction in these markers, thus suggesting the ability of E. chlorantha the treatment to protect against diabetes-induced kidney damage.

Data obtained from our study showed that coadministration of lisinopril and E. chlorantha attenuated the development of kidney impairment caused by the diabetic condition. The development of pathological changes including elevation of serum kidney biomarkers has been documented to occur in DM [30]. Our result indicates that the use of E. chlorantha in diabetes improved kidney function and that the efficacy may not be increase with simultaneous administration of lisinopril.
Our results also showed that cardiac function was restored in the treated groups compared with the untreated diabetic rats. Although administration of $E$. chlorantha in diabetic rats was shown in the present study to improve cardiac function, the result of our study suggest that the effect may be more pronounced when co-administer with lisinopril. This thus implies that a synergistic effect may occur from the interaction of both agents. Previous authors have reported that lisinopril administration may improve myocardiac injury in hypertensive patients [28]. Our result corroborates this report.

The result of the haematological study shows that although diabetic condition may be associated with reduction in haemoglobin and erythrocytes level, combined administration of lisinopril and E.chlorantha restores these parameters similar to what may be achieve when the extract is administered singly. Combined administration of the two agents however proved to be better in restoring PCV than the administration of the extract alone. A study indicated that lisinopril has the potential to stimulate erythropoietin release from the kidney which is the humoral regulator of RBC production [27]. Our study thus demonstrated a synergistic interaction in restoring PCV value when lisinopril was co-administered

Table 5 Effect of combined administration of lisinopril and ethanolic bark extract of E. chlorantha on Erythrocyte count, Leucocyte count, Heamoglobin and PCV level in type 2 diabetic rats

\begin{tabular}{|c|c|c|c|c|c|}
\hline Group & Treatments & Erythrocyte count million/ $\mu \mathrm{L}$ & Leucocyte count $\times 10^{9} / \mathrm{L}$ & Heamoglobin (g/dl) & PCV (\%) \\
\hline Control & Distilled water & $5.41 \pm 0.99^{\mathrm{a}}$ & $8.14 \pm 2.09^{a}$ & $13.00 \pm 1.47^{a}$ & $45.14 \pm 1.77^{\mathrm{a}}$ \\
\hline Model & STZ-fructose+ distilled water & $3.48 \pm 0.49^{b}$ & $14.66 \pm 0.98^{b}$ & $7.32 \pm 2.50^{\mathrm{a}}$ & $33.26 \pm 2.27^{b}$ \\
\hline $\mathrm{T} 1$ & Extract only & $5.00 \pm 0.27^{\mathrm{a}}$ & $7.15 \pm 1.52^{\mathrm{a}}$ & $12.73 \pm 0.96^{\mathrm{a}}$ & $48.23 \pm 3.44^{\mathrm{a}}$ \\
\hline $\mathrm{T} 2$ & Glucophage only & $5.35 \pm 0.49^{a}$ & $5.55 \pm 0.66^{a}$ & $11.79 \pm 1.80^{\mathrm{a}}$ & $46.83 \pm 3.63^{\mathrm{a}}$ \\
\hline $\mathrm{T} 3$ & Extract + Lisinopril & $5.75 \pm 0.29^{a}$ & $5.47 \pm 0.96^{\mathrm{a}}$ & $14.07 \pm 1.29^{\mathrm{a}}$ & $52.25 \pm 1.71^{c}$ \\
\hline T4 & Glucophage + Lisinopril & $5.84 \pm 0.48^{\mathrm{a}}$ & $4.88 \pm 0.71^{\mathrm{a}}$ & $14.91 \pm 1.44^{\mathrm{a}}$ & $50.14 \pm 2.20^{c}$ \\
\hline T5 & Lisinopril only & $4.840 \pm 0.11^{a}$ & $7.62 \pm 1.16^{\mathrm{a}}$ & $12.69 \pm 0.76^{\mathrm{a}}$ & $48.64 \pm 2.49^{a}$ \\
\hline
\end{tabular}

Results are mean \pm SD of seven determinations

Values in the same column with similar superscripts $(a, b$ or $c)$ are not significantly $(p>0.05)$ different from each other 

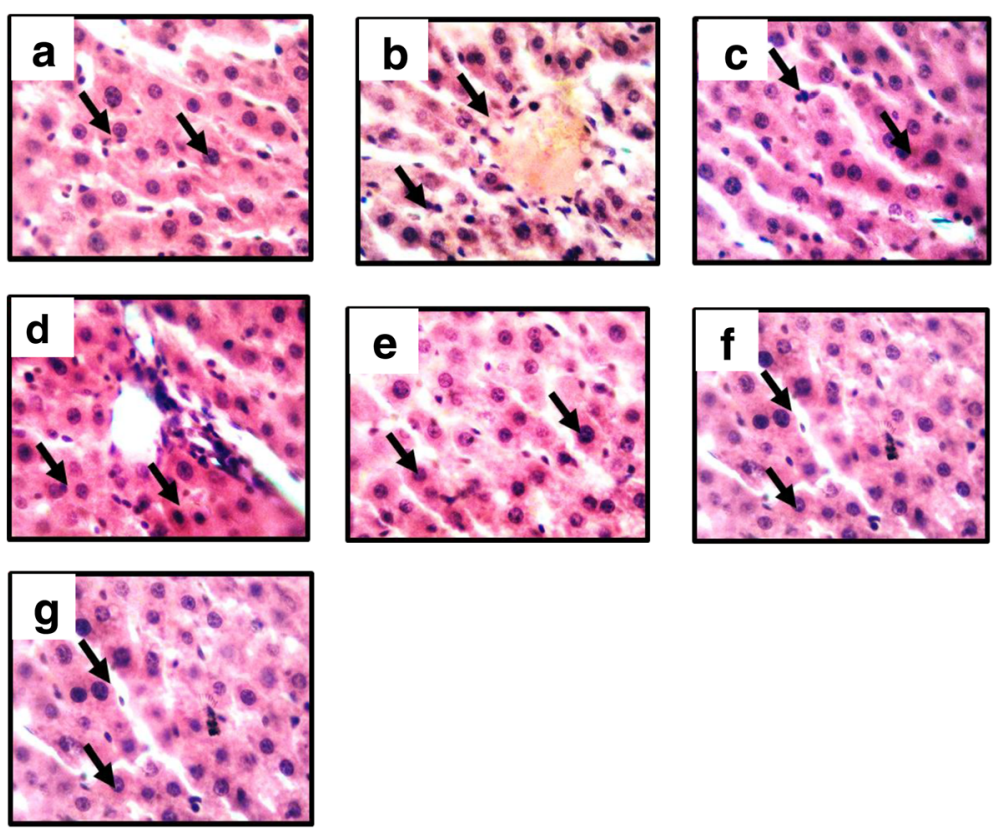

Fig. 1 Representative photomicrograph $(\times 400$, Haematoxylin and eosin stained) of the liver of (a) control, (b) model group; (c) Extract treated; (d) Glucophage treated; (e) Extract + lisinopril treated (f) Glucophage + lisinopril treated; (g) Lisinopril treated rats
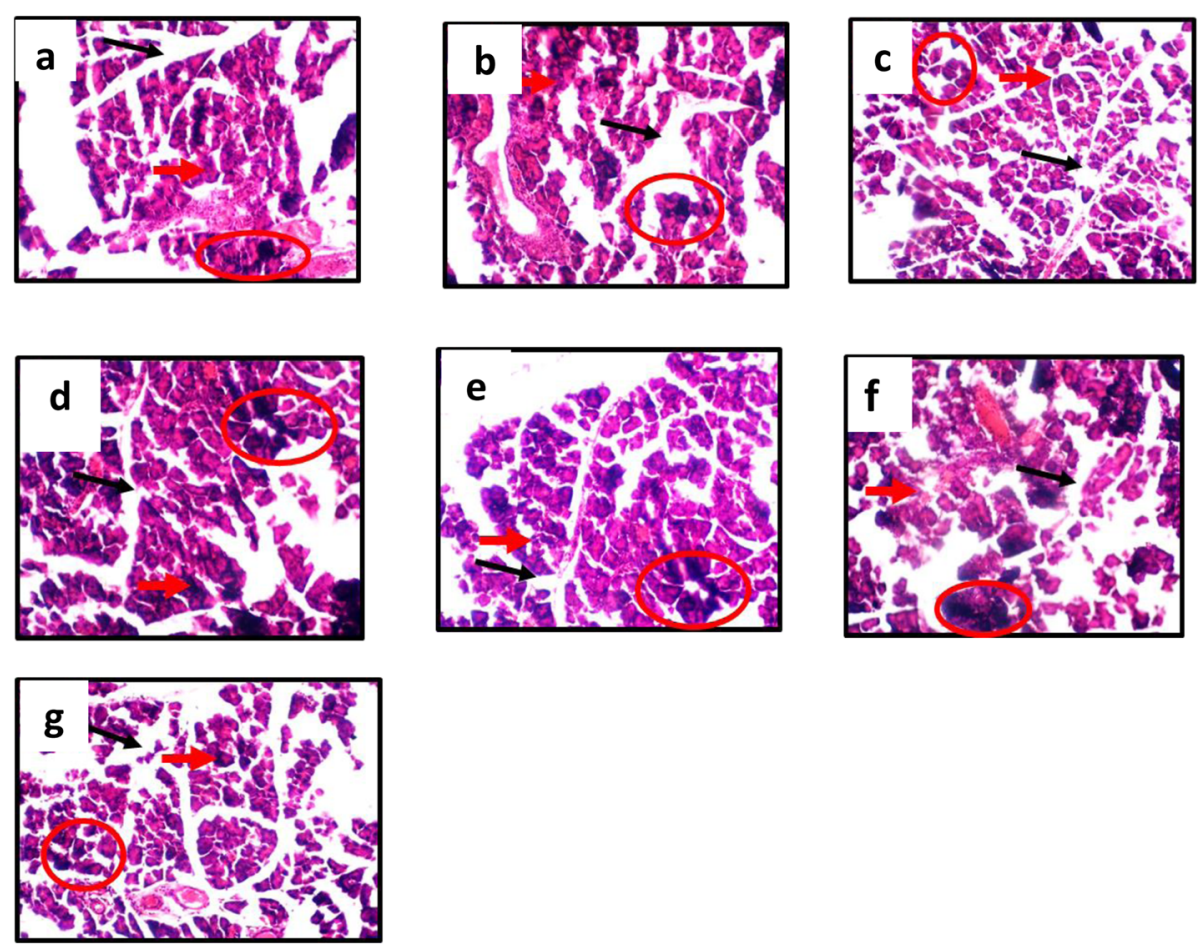

Fig. 2 Representative photomicrograph ( $\times 400$, Haematoxylin and eosin stained) of the pancreas of (a) control, (b) model group; (c) Extract treated; (d) Glucophage treated; (e) Extract + lisinopril treated (f) Glucophage + lisinopril treated; (g) Lisinopril treated rats- 
with the E. chlorantha compared to single administration of the extract.

Histopathological examination of tissues is useful in identifying the type of lesions caused by xenobiotics and is acknowledged as the most sensitive end point for detecting organ toxicity [15]. It is also useful in providing information about acute or chronic effects of toxic substances that may not be detected by other biomarkers [4, 12]. In this study the histology of the pancreas showed diminished expression of islet cells in the diabetic rats in contrast to the control with normal histoarchitecture cells indicating that diabetes may be associated with cells damage. The liver histology of the model group and the extract and lisinopril co-administered group showed fatty liver while the other groups did not. This also buttress the fact that single administration of the extract had better therapeutic and less toxicity effect on liver function compared to co-administration of the extract with synthetic drug.

\section{Conclusion}

This study concluded that E chlorantha is not toxic at acute dose and that combine administration of $E$ chlorantha extract and lisinopril at sub-acute dose in diabetes may aggravate liver dysfunction associated with diabetes.

\section{Acknowledgements}

The authors are grateful to Dr. Emeka of the Central Research Laboratory, llorin for the kind assistance received and also to our research students who participated in the study.

\section{Authors' contributions}

LBI carried out experimental work, plant collection, literature search and manuscript preparation. EOA supervised the study and revised the manuscript for publication. All authors have read and approved the manuscript.

\section{Funding}

Funding for this study was provided by the researcher.

\section{Availability of data and materials}

Not applicable in this section.

\section{Ethics approval and consent to participate}

The study was designed and conducted following the Department Animal Ethics Committee guidelines (No. KSUMB/005/01/018).

\section{Consent for publication}

Not applicable in this section.

\section{Competing interests}

The author declare that they have no competing interest.

Received: 19 December 2019 Accepted: 6 May 2020

Published online: 23 May 2020

\section{References}

1. Adesokan AA, Akanji MA, Yakubu MT. Antibacterial potentials of aqueous extract of Enantia chlorantha stem bark. Afr J Biotech. 2007;6(22):2502-5.

2. Ajani EO, Ogunlabi OO, Adegbesan BO, Adeosun $\mathrm{OE}$, Akinwande O. Nigerian mistletoe (Loranthus micranthus Linn) aqueous leaves extract modulates some cardiovascular disease risk factors in monosodium glutamate induced metabolic dysfunction. Afr J Biotech. 2014;13(39):989-98.
3. Akyuz F, Tekin N, Aydin O, Temel HE, Isikli B. The effect of metformin and exercise on serum lipids, nitric oxide synthase and liver nitric oxide levels in streptozotocin-nicotinamide induced diabetic rats. Afr J Pharm Pharmacol. 2012;6(5):336-42.

4. Amacher DE, Schomaker SJ, Boldt SE, Mirsky M. The relationship among microsomal enzyme induction, liver weight and histological change in cynomolgus monkey toxicology studies. Fd Chem Toxicol. 2006;44(4):52837.

5. American Diabetes Association. Diagnosis and classification of diabetes mellitus. Diabet Care. 2012;37(1):81-90.

6. Daniel WC, Eleanar T, Roger F, Roz-lynn B. Immunoenzymatic assay for creatine kinase MB with subunit specific monoclonal antibodies compared with an immunochemical method and electrophoresis. Clin Chem. 1985; 31(3):465-9

7. de Lima T, Vieira M, Huang SM. Botanical-drug interactions: a scientific perspective. Planta Med. 2012;78:1400-15.

8. Droste HT, de Vries RA. Chronic hepatitis caused by lisinopril. Nether J Med. 1995;46:95-8.

9. Erbey JR, Silberman C, Lydick E. Prevalence of abnormal serum alanine aminotransferase levels in obese patients and patients with type 2 diabetes. Am J Med. 2000;109:588-90.

10. Grove J, Daly AK, Bassendine MF, Day CP. Association of a tumor necrosis factor promoter polymorphism with susceptibility to alcoholic steatohepatitis. Hepatology. 1997;26:143-6.

11. Hussain SA, Marouf BH. Flavonoids as alternatives in treatment of type 2 diabetes mellitus. Acad J Med Plants. 2013;1(2):031-6.

12. Jadhav JP, Parshetti GK, Kalme SD, Govindwar SP. Decolourization of azo dye methyl red by Saccharomyces cerevisiae MTCC 463. Chemosphere. 2007;68(2):394-400.

13. Khardori R. Changing paradigms in type 2 diabetes mellitus. Ind J Endocrinol Metab. 2013;17(1):S68-71.

14. Kuate D, Pascale A, Kengne N, Cabral PNB, Gabin KA, Wan BM. Tertapleura tetraptera spice attenuates high-carbohydrate, high fat diet-induced obese and type 2 diabetic rats with metabolic syndrome. Lipids Health Dis. 2015; 15(50):1-13.

15. Lanning LL, Creasy DM, Chapin RE, Mann PC, Barlow NJ, Regan KS, Goodman DG. Recommended approaches for the evaluation of testicular and epididymal toxicity. Toxicol Pathol. 2002:30(4):507-20.

16. Litherland GJ, Hajduch E, Gould GW, Hundal HS. Fructose transport and metabolism in adipose tissue of Zucker rats: diminished GLUT5 activity during obesity and insulin resistance. Mol Cell Biochem. 2004;261:23-33.

17. Lorke D. A new approach to practical acute toxicity testing. Archieve Rev. 1983;54:275-87.

18. Luis-Rodríguez D, Martínez-Castelao A, Górriz UL, de Álvaro F, NavarroGonzález F. Pathophysiological role and therapeutic implications of inflammation in diabetic nephropathy. World J Diabetes. 2012;3(1):7-18.

19. Martinez FJ, Rizz RA, Romero JC. High-fructose feeding elicits insulin resistance, hyperinsulinism, and hypertension in normal mongrel dogs. Hypertension. 1994;23:456-63.

20. Mohammed B, Amal AHS, Ayoub C, Fathia EG, Abdeirahim N, Laila B, Naima K. Phytochemical screening and Toxicological study of Aristolochia bactica Lin. Roots: Histopathological and Biochemical evidence. J Toxicol. 2019;2019: 8203832 PMCID PMC 6377958

21. Mohan V, Deepa R, Rani SS, Premalatha G. Chennai urban population study (CUPS no.5). Prevalence of coronary artery disease and its relationship to lipids in a selected population in South India: the Chennai urban population study (CUPS no. 5). J Am Coll Cardiol. 2001;38(3):682-7.

22. $\mathrm{NIH}$. National Research Council update of the guide for the care and use of laboratory animals. Washington: Nat Acad Press; 2011. PMID: 21595115.

23. O'Brien RM, Granner DK. Regulation of gene expression by insulin. Biochem J. 1991;278:609-19.

24. OECD. The OECD guidelines for testing of chemicals, 423. Acute oral toxicity test. Paris: Organization of Economic Co-operation Development; 2001.

25. Ogbonnia SO, Mbaka GO, Anyika EN, Ladiju OH, lgbokwe N, Emordi JE, Nwakakwa N. Evaluation of anti-diabetics and cardiovascular effects of Parinari curetellifolia seed extract and anthoclista vogelli root extract individually and combined on postprandial and alloxan-induced diabetic albino rats. Br J Med Medic Res. 2011:1:146-62.

26. Peters T. Determination of total proteins. Clin Chem. 1968;14:1147-59.

27. Polenakovic M, Sikole A. Is erythropoietin a survival factor for red blood cells? J Am Soc Nephrol. 1996;7(8):1178-82. 
28. Przyklenk Kloner RA. Cardioprotection by ACE inhibitors in acute myocardial ischemia and infarction. Basic Res Cardiol. 1993;88:139-54.

29. Reitman S, Frankel SA. Colorimetric method for the determination of serum glutamic- oxaloacetate and glutamic pyruvate transaminase. Am J Clin Pathol. 1957;28:56-61.

30. Roma-Bikai OJ, Moleli M, Cainel F, Rivegerera GM. The prevalence of microalbuminuria and associated factors among patients with type 2 diabetes in Botswana. Niger J Clin Pract. 2018;11:1430-7.

31. Thapa BR, Anuj W. Evaluation of liver: test and their interpretation. Ind Ped. 2007;74(7):663-71.

32. Tietz NW, Prude EL, Sirgard-Anderson O. In: Burtis CA, Ashwood ER, editors, Tietz Textbook of Clinical Chemistry. London: Saunders Company; 1994. p. 1354-74.

33. Tsabang N, Fokou PV, Tchokouaha LR, Noguem B, Bakarnga-Via I, Nguepi MS, Nkongmeneck BA, Boyom FF. Ethnopharmacological survey of Annonaceae medicinal plants used to treat malaria in four areas of Cameroon. J Ethnopharmacol. 2012;139(1):171-80.

34. Wilson RD, Islam MS. Fructose-fed streptozotocin-injected rat: an alternative model for type 2 diabetes. Pharmacol Rep. 2012;64(1):129-39.

35. OECD Handbook: good laboratory practice (GLP): quality practices for regulated non-clinical research and development 2 nd ed. Geneva: WHO; 2009. pp. 3-50.

36. Wright PJ, Leatherwood PD, Plummer DT. Enzymes in rat urine: Alkaline phosphatase. Enzymologia. 1972;42:317-27.

\section{Publisher's Note}

Springer Nature remains neutral with regard to jurisdictional claims in published maps and institutional affiliations.

\section{Submit your manuscript to a SpringerOpen ${ }^{\circ}$ journal and benefit from:}

- Convenient online submission

- Rigorous peer review

- Open access: articles freely available online

- High visibility within the field

- Retaining the copyright to your article

Submit your next manuscript at $\boldsymbol{\nabla}$ springeropen.com 